\title{
Changes in increment of trees diameters on plant-soil treatment system after long-term irrigation with domestic sewage
}

\author{
Katarzyna Pawęska, Krzysztof Kuczewski \\ Wrocław University of Environmental and Life Sciences, Poland \\ The Faculty of Environmental Engineering and Geodesy \\ ${ }^{*}$ Corresponding author's e-mail: katarzyna.paweska@up.wroc.pl
}

Keywords: biomass, effluent irrigation, tree diameter, poplar, plant-soil treatment system.

\begin{abstract}
Carbon dioxide sequestration and its long-term immobilisation in biomass is recently an extremely significant problem. Its greatest reserves occur in forests growing all over the globe. A human being, through their conscious action, ought to affect, among other things, the amount of carbon dioxide discharged into the atmosphere and its rational management. Here, quite a good solution seems to be the immobilisation of $\mathrm{CO}_{2}$ in biomass of plants, and in particular, in trees, characterised by their longevity, which are used most frequently for that purpose.

Such carbon dioxide management allows for its several-decade immobilisation within living plants, while a further processing of wood mass allows for halting it for consecutive years in products manufactured. Additionally, in the case when within a selected land planted with trees the effluent irrigation is being carried out, simultaneous sewage treatment is also an advantage. By using plants characterised by intense increment in biomass within facilities, also biogens occurring in effluents may be effectively removed.

In the analysed case, sewage treatment consisted in entry of household sewage into a prepared surface which was previously subject to mechanical purification. All the sections were sown with grass mixture and plantings of poplar were used. Observations were made during the period of 17 years. The effluents entered onto the surface of the sections and the effluents outflowing from the facility were subject to a physicochemical analysis in order to determine the operational efficiency of a plant - soil treatment system. Also, a threefold inventory of a forest stand was made in order to determine the increment in trees.

The last inventory was made in 2014. Based on dendrological characteristics, the average volume of wood mass obtained from the land irrigated with effluents was assessed.

A rational management of effluents on the grounds without any central drainage allows for a parallel solution to some problems. First of all, purification of effluents in a natural environment by closing the matter cycle, and additionally contributing to the limitation of carbon dioxide emission by its halting in plant biomass.
\end{abstract}

\section{Introduction}

The management of waste and wastewater through their treatment in the soil profile has a long-standing tradition both in Poland, and in the world (Boćko 1979, Montiel-Vasquez et. al 1995, Oster 1994, Paluch 1984, Bień et. al 2014, Joniec et. al 2012). Many arguments weigh in favour of such use not only of household origin, but also industrial ones. Irrigation of soil with effluents considerably improves their water and nutritional balance, predominantly due to a significant amount of water supplied and essential content of nutritional substances. An outer layer of soil, revealing its highest activity acts as a peculiar filter, and developed microflora and microfauna encourage decomposition of pollution which is entered along with effluents. A due attention shall be paid to a type of soil (permeable one) and the depth of occurrence of subsurface water table. The effluent management going towards an agricultural use ought to be carried out in such manner as to avoid a negative result of sewage introduction into the environment - a precise determination of the quality of sewage and a demand of plants for fertilising substances, irrigation rates and annual volumes of sewage introduced into the ground allows to avoid the risk of subsurface water pollution with biogenic compounds, salts and organic matter. A significant process preparing effluents for a further use within the soil is their mechanical purification. Disposal of thicker suspension fractions allows for a more effective use of components effluent and reduction in negative processes of soil bed clogging.

Sewage introduction into the soil ought to be carried out in such manner as to assure aerobic decomposition of pollution within it and its stabilisation both as a result of activity of soil microorganisms, and with involvement of plants. 
The active layer of soil contributes to the reduction of greenhouse gases release. Additionally, it reduces water outflow (biogenic compounds along with it) from irrigated surface through evaporation, evapotranspiration and plant uptake. The research conducted on soil capacity to retain carbon revealed that soil is the greatest $\mathrm{CO}_{2}$ reservoir in the world (Lal 2004). Furthermore, increasing an inflow of organic matter considerably contributes to the increase in sequestration capacity of $\mathrm{CO}_{2}$ (Paustian 2014). In the process of carbon retention and its compounds within the soil the presence and activity of soil organisms is also significant because of their active participation in the carbon cycle.

The organisms, which are recognised as contributing to the increase of soil ability to accumulate $\mathrm{CO}_{2}$ most, are earthworms, which in result of their life activity interact with physical and chemical mechanisms processing organic matter within the soil. The main factor influencing the ability to carbon retention from a free $\mathrm{CO}_{2}$ is protection of the organic matter against decomposition, which is obtained by creation of soil aggregates. The living activities of earthworms, which affect the soil stabilisation, have a significant influence on soil aggregates creation (Sanchez-de Leon et al. 2014).

Ions of heavy metals from effluents discharged to soil are immobilised permanently (Fine et al. 2006). Apart from peculiar soil properties used on the grounds irrigated with effluents (permeability, low occurrence of subsurface water), the surface is planted with flora in order to intensify purification processes. Depending on the type of purification plant (e.g. irrigated fields, ground beds) different species of plants are used. The most important function of plants confirmed by many authors (Bouwer 1992, Carr et al. 2004, Tanner 2001) is shaping of a proper water flow through the soil profile, which is obtained owing to a characteristic structure of shoots (the skeleton function). The roots and the sphere produced around them (rhizosphere) assure the surface for the growth of a biofilm containing, among other things, bacteria, fungi,and protozoans (Badura 2006, Pedrero et al. 2010). Within the rhizosphere layer adhering to the roots owing to the life activity of plants, the occurrence of oxygen conditions is possible, and consequently - multiplication of bacteria leading an oxygen decomposition of the matter occurring in sewage. Combination of such process with anaerobic decomposition occurring within deeper ground layers assures removal of pollutants from sewage in a comprehensive manner.

The amount of components collected from sewage discharged into the surface of the facility is closely bound up with type of a plant used for planting, its age, irrigation regimen, environmental conditions and the sewage quality. Constructed wetland technology $(\mathrm{CW})$ is a solution oriented towards intensification of purification processes which is along with the use of plants. Levels of pollution reduction for the $\mathrm{CW}$ solutions are diversified. According to Tanner (Tanner 2001) the reduction levels can fluctuate between 12 and $66 \%$ for basic pollution indices. On the other hand, with simulation of different hydraulic conditions we can achieve higher treatment efficiency - 65-96\% for vertical flow and 56-85\% for vertical flow (Jóźwiakowski 2012).

The technology uses annual or perennial plants, e.g. grass mixtures, reed and willow, which are characterised by intensive growth and possibility to obtain up to several crops during vegetation period (Jóźwiakowski 2012, Jóźwiakowski
2005). The organic matter, which accumulates on the surface and the first $100 \mathrm{~mm}$ of filling, is discharged along with sewage into the bed surface. The flow through the bed is forced by particular structures of beds. The organic matter entered along with the irrigation rate spreads out within the outer layer of soil, however flora growing in the bed does not have a significant participation in such process (Tanner 2001). The plants during the growing season through taking up the elements essential for development contribute to reduction of biogens. Accumulation grade of biogens in plant biomass strictly depends on a species of plant, its age and also the morphological part. One of the most popular native species used in sewage purification systems is common reed (Phragmites australis) due to its capabilities to accumulate biogens. Accumulation differences also emphasise within different parts of the plant. Stalks reveal greater capabilities to accumulate nitrogen than leaves (Jóźwiakowski 2005). A similar tendency connected with different levels of biogene accumulation is observed in the case of willow saplings (Salix viminalis) - accumulation of phosphorus was relatively balanced, great differences were observed in the case of nitrogen. The willow is universally used on such surface where sludge fertilising is employed since it reveals a great bioaccumulation capacity of heavy metals and micro and macroelements (Różanowski et al. 2012).

The sewage irrigation may also be applied in the case of purification plants constructed for single premises (irrigation of lawns) (Baryła 2005, Wiśniewska-Kadżajan and Jankowski 2012) and to irrigate urban greenery (street-adjacent plantings). The tree biomass as the source of renewable energy may affect the decrease in demand for energy deriving from fossil fuels (Pandey and Srivastava 2012) and therefore the combination of sewage purification and irrigation (mainly trees) seems to be legitimate. According to the research by Padney and Srivastava (Pandey and Srivastava 2012) selected local species of trees revealed a high reduction of the nitrogen content, organic matter (expressed by $\mathrm{BOD}_{5}$, COD), phosphorus, potassium and sodium.

The employment of effluent irrigation on the surface planted with tree saplings is a proper move towards a balanced management of water resources, and simultaneously it allows to intensify sewage purification processes and immobilise pollutants brought along with it onto the ground surface for a longer period of time.

Employment for that purpose of sewage purification of large facilities, where purification capabilities of soil and trees planted are used, has a favourable influence not only on removal of pollutants contained in sewage, but also it fulfils the task of storage for carbon dioxide, the content of which in atmospheric air within the space of years decreased. A greater emission of greenhouse gases results in climatic changes and fight against them is one of the chief environmental challenges of the current century. One of the methods of fighting an excess concentration of carbon dioxide in atmospheric air is using natural "tanks" of carbon dioxide - plants, ecosystems to absorb and retain $\mathrm{CO}_{2}$ (Freedman 2014).

The objective of this paper was an assessment of changes of the increment in diameter at breast height of trees planted on the surface of the facility adapted to a long-term sewage collection (a sewage treatment plant). The assessment was made after a long-standing irrigation cycle with household sewage and taking into account the quality of sewage introduced onto the 
selected surface. Characteristics of changes of the increment in poplar was referred to intensive sewage management carried out on the facility surface with a special consideration of the quantity and quality of sewage introduced and obtained purification results.

\section{Methodology and research facility}

The research facility working since 1996 is localised in Brzeźno in Dolnośląskie Voivodeship in Prusice municipality. The municipality has a partially installed sewage system connected to two purification plants. Household not connected to the sewage system are equipped with septic tanks (Pawęska and Kuczewski 2008).

The investigated purification plant works in a plant-soil bed technology. It collects household sewage coming from a neighbouring village with 350 inhabitants. The technology applied consists of two purification steps: mechanical, taking place in two septic tanks with a capacity of $55 \mathrm{~m}^{3}$ each where effluents are subject to sedimentation processes. Next, after a preliminary mechanical purification, the effluents are introduced through a dosing and accumulation tank onto the plant-soil matrix.

The research was conducted within the facility adapted to a long-term irrigation. Irrigation was carried out within 21 sections of a surface area of 0.11 ha each, planted with poplar and ash samplings. 21 sections were grouped into 4 segments ended with controlling well (Fig. 1). Additionally, irrigated beds were sown with grass mixtures, in which the following

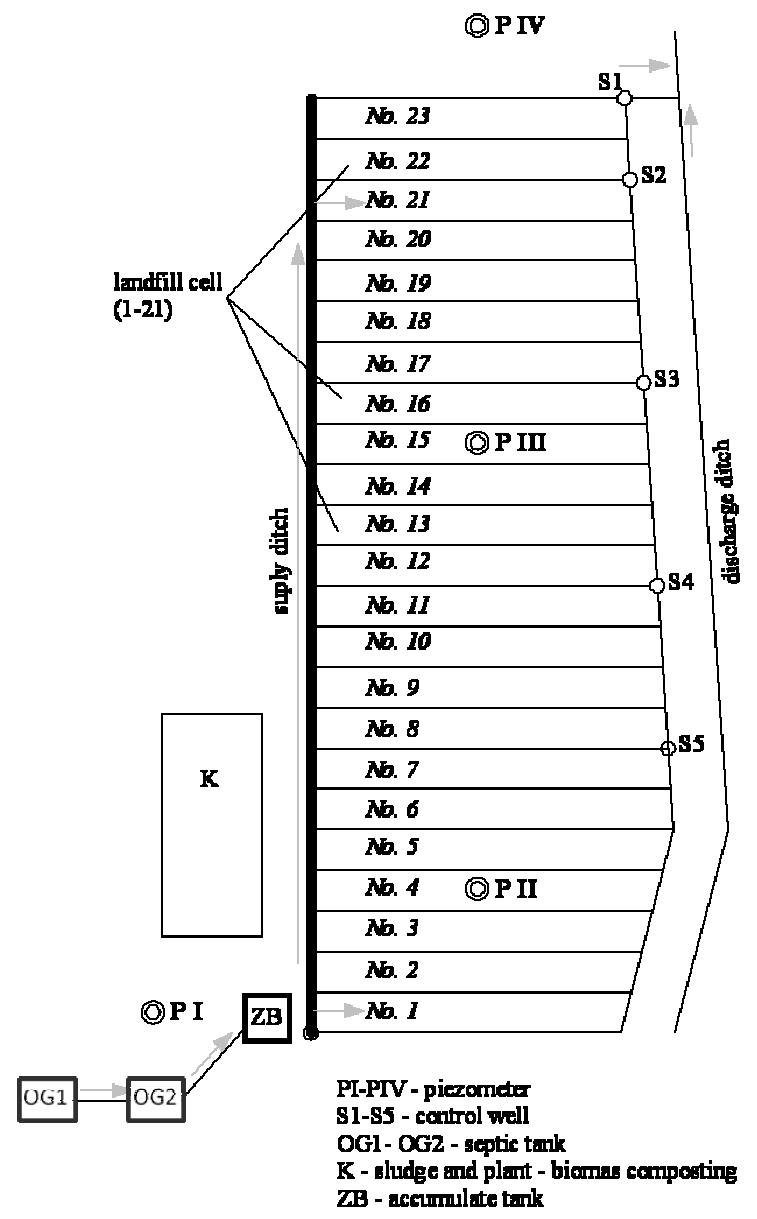

Fig. 1. Diagram of plant-soil sewage treatment system in Brzeźno species dominated: red fescue, creeping thistle, orchard grass, bush vetch. The capacity of a dosing and accumulation tank $\left(110 \mathrm{~m}^{3}\right)$, corresponded to a single irrigation rate of $97 \mathrm{~mm}$ used within the facility.

The sewage was introduced onto a particular section at intervals of 21 days, a decreased load of $50 \mathrm{~mm}$ was employed during winter months. The section surface is formed with a slope allowing gravitational effluent to run off the surface. Physicochemical composition of the effluents after the mechanical treatment and the final effluents from the purification system were investigated. The quality of subsurface water beneath the purification system was permanently monitored. The investigation included analyses of organic matter (BOD and COD, suspension solids) and concentration of nitrogen and total phosphorus. Concentrations of chosen pollution indexes were measured based on standards: BOD - PN-EN 1899-1:2002 (dilution method); COD - chromium method; suspended solids - sample filtration through preweighed filter, drying at $105^{\circ} \mathrm{C}$ for $24 \mathrm{~h}$ and reweighing the filter; total nitrogen and total phosphorus - colorimetric method. All chemical analyses were conducted in Laboratory of Wroclaw University of Environmental and Life Science. Additionally, in 2003, 2005, 2008 and 2014 a characteristics of poplar stand condition was drawn up with consideration of diameter size of the trees (measurement of diameter at breast height $-130 \mathrm{~cm}$ ) and the number of trees which did not survive during exploitation period. In 2003 and 2004 the analysis of composition of the poplar wood biomass and grass collected from the surface of the purification plant was made.

\section{The research findings and discussion}

From 1996 the treatment system was fed with household sewage. This was a mixture of sewage coming from residential buildings and sewage delivered by liquid manure spreaders. The amount of sewage in 2013 used for irrigation was over 1.5 times higher than in 2004 (Fig. 2). Also, the percentage share of sewage delivered by liquid manure spreaders and household wastewater increased from $26 \%$ in 2003 up to $62 \%$ in 2013.

During the first years of exploitation, the purification plant was mainly supplied with domestic wastewater. It is estimated that for a proper functioning of the purification plant employing biological methods, the share of sewage coming from cesspools shall not exceed 10\% (Bugajski and Satora 2009).

A design irrigation rate changed in a similar manner. The amount of sewage introduced onto a selected section increased successively. The load of the purification plant diversified depending on a segment. The greatest irrigation rates were introduced onto the sections of segment 1 in early years of work, and next increased sewage rates feeding segment III and IV were observed (Table 1).

The composition of sewage introduced onto the surface of biological beds is extremely significant, especially when in purification processes, the plants are used and a specific ecosystem which was created within the outer layer of bed irrigated with sewage. Not all kind of sewage can be treated in plant-soil treatment plant. Sewage composition used for irrigation should be properly selected in terms of plants needs as well as for physicochemical composition and type of soil. The physicochemical composition of effluents is presented in Tab. 2 . 
The parameters of sewage brought to purification plants changed in terms of concentration. The highest concentration observed already occurred after the activation period of bed. The increase in value concerned, among other things, the organic matter ( $\mathrm{BOD}_{5}, \mathrm{COD}$ and suspension solids). This influenced the amount of carbon supplied along with sewage to plants used on beds, and also it had its reflection in changes occurring within the soil profile (accumulation of fine suspension fractions in free spaces between the seeds).
Also, concentration changes were affected by disturbances in proportion of sewage inflowing to the accumulation tank localised within the purification plant and sewage delivered by liquid manure spreading. During the entire exploitation period observed were the years when the organic matter was characterised by a low susceptibility to biochemical decomposition (Pawęska and Kuczewski 2008). This might have affected a considerable accumulation of insoluble suspension fractions within the soil profile.
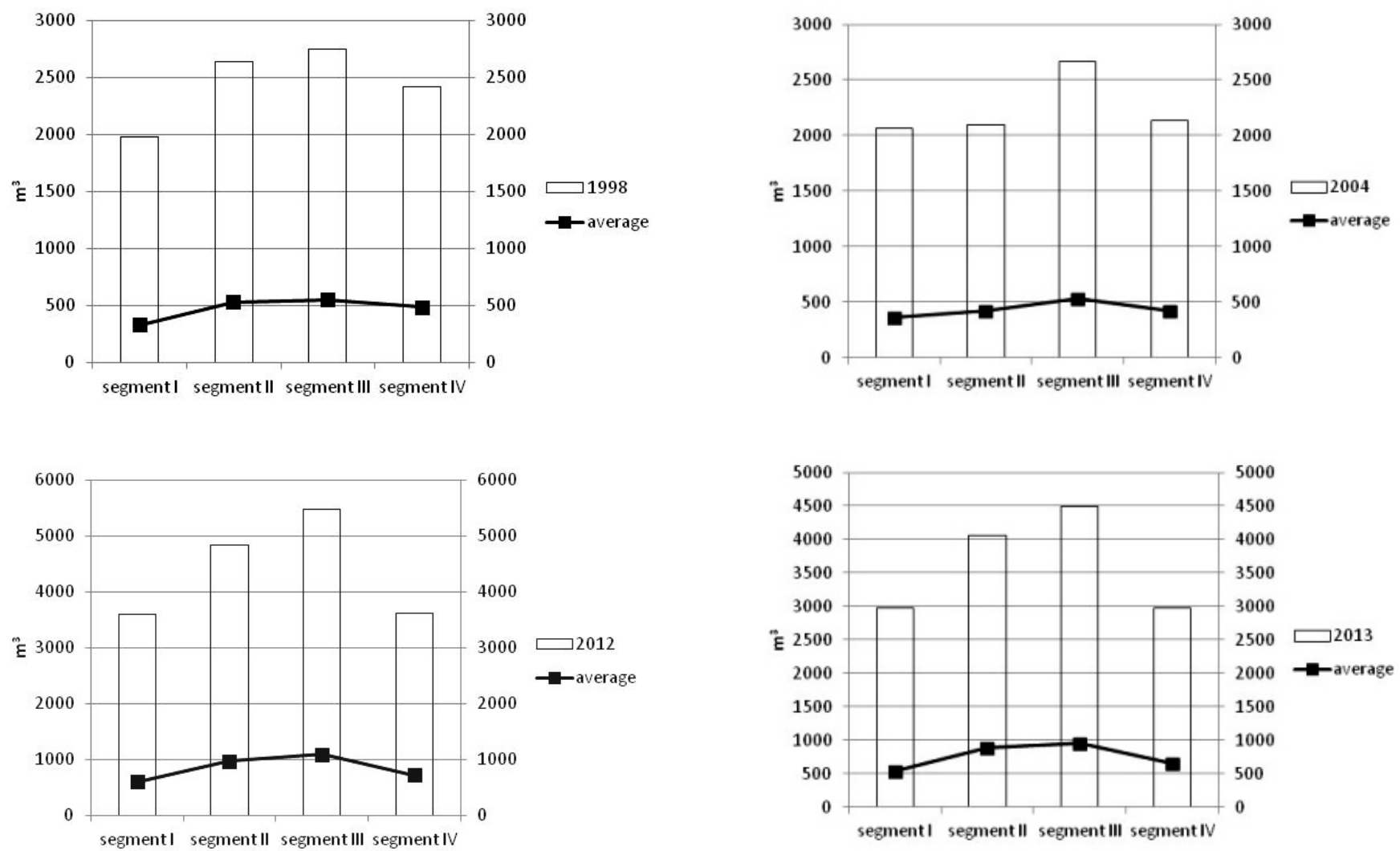

Fig. 2. The total annual and average amount of wastewater introduced into beds during the sewage treatment plant starting $(1998,2004)$ and after years of irrigation $(2012,2013)$

Table 1. The average dose of wastewater introduced into plots during the sewage treatment plant starting (1996) and after years of irrigation $(2011,2013)$

\begin{tabular}{|c|c|c|c|c|}
\hline \multirow{2}{*}{ Year of operation } & \multicolumn{4}{|c|}{ The average irrigation dose [mm] } \\
\cline { 2 - 5 } & segment I & segment II & segment III & segment IV \\
\hline 1996 & 558 & 350 & 350 & 380 \\
\hline 2011 & 951 & 802 & 949 & 1021 \\
\hline 2013 & 544 & 881 & 995 & 657 \\
\hline
\end{tabular}

Table 2. The average concentration of pollution in wastewater after mechanical treatment introduced in sewage treatment plant area in first year of operating (1996) and long-term irrigation (2013)

\begin{tabular}{|c|c|c|c|c|c|}
\hline Year & $\begin{array}{c}\mathrm{BOD}_{5} \\
\mathrm{mgO}_{2} \times \mathrm{dm}^{-3}\end{array}$ & $\begin{array}{c}\mathrm{COD} \\
\mathrm{mgO}_{2} \times \mathrm{dm}^{-3}\end{array}$ & $\begin{array}{c}\mathrm{N} \text { total } \\
\mathrm{mgN} \times \mathrm{dm}^{-3}\end{array}$ & $\begin{array}{c}\mathrm{P} \text { total } \\
\mathrm{mgP} \times \mathrm{dm}^{-3}\end{array}$ & $\begin{array}{c}\text { Suspension } \\
\text { solid } \\
m g \times \mathrm{dm}^{-3} \\
\end{array}$ \\
\hline 1996 & 163,1 & 328,6 & 65,2 & 9,5 & - \\
\hline 2011 & 400,0 & 616,3 & 97,8 & 17,2 & 196,3 \\
\hline 2013 & 233,0 & 517,5 & 69,2 & 13,8 & 194,8 \\
\hline
\end{tabular}


Sewage purification oriented to agricultural use combines co-operation of soil and vegetable environment. In the case of a monitored purification plant, due to a type of soil and the year-long principles of purification, a special type of plants was selected - plantings of Populus robusta and ashtree (Fraxinus excelsior). Additionally, the surface was sown with grass mixtures containing, among other things, creeping thistle (Cardus crispus), red fescue (Festuca rubra), and orchard grass (Dactylis glomerata). Tree species, such as poplar, are decidedly better suitable for grounds irrigated with sewage due to rapid increment. The use of trees in such solutions allows to immobilise pollution, mainly carbon and biogens in plant biomass for a longer period of time. Additionally, a more extensive root system than in lower plants allows for taking micro and macroelements from deeper parts of the soil profile. However, when intensively irrigated, there is the necessity of changing a forest stand more frequently. In the case of poplar, fields subject to sewage irrigation ought to be changed within the period of 10 years.

During the period of a long-standing exploitation of the facility, a multiple inventory of forest stand was carried out. First of all, the amount of saplings and their diameter at the height of $130 \mathrm{~cm}$ was measured. The characteristic of forest stand was carried out during the activation period of bed (before reaching a full efficiency of the purification plant) in 1997, and next in 2003, 2005, 2008 and 2014 during the period of intensive sewage irrigation and at the time of a potential change of plantings. In the case of permanent, long-term sewage irrigation within the facility, the increase in diameter of trees planted was observed (Fig. 3). Differences in the size of trees were noticeable both within the segments, and also in individual rows of single sections. Average diameter of saplings in 2003 measured at the height of $130 \mathrm{~cm}$ was equal to $13.4 \mathrm{~cm}$ $(n=1283)$. In 2014, the diameter reached $32.7 \mathrm{~cm}(\mathrm{n}=631)$. The average increment was $38.7-44.9 \%$. Because of such intensive growth of trees, forest stand losses resulting from strong winds and irregular cutting out of the trees carried out by the facility explorers were observed. In comparison with primary plantings, $73 \%$ of forest stand loss was observed. The greatest increase in diameters in comparison with measurements made in 2003 was recorded for the trees planted in segment 4 of the

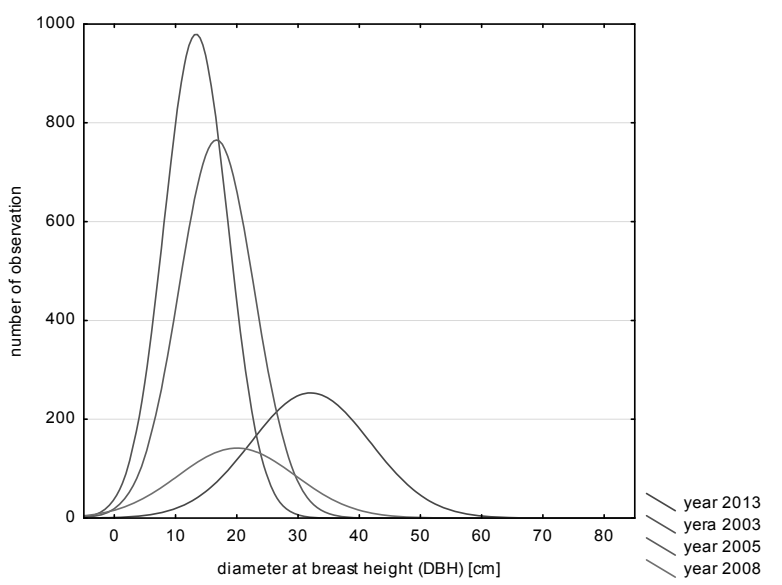

Fig. 3. The diversity of $\mathrm{DBH}$ (diameter at breast height) trees in the area irrigated with domestic wastewater treatment plant water purification plant. This was probably connected with a balanced irrigation carried out during early years of exploitation (Fig. 2). Segment 2 was also characterised by the most stable increment in trees diameters. The poplar with the greatest diameters covered segment 1 intensively fed with sewage, and in years 2003-2006 this was overloaded with pollutants (Pawęska and Kuczewski 2008).

A natural process when using plants within irrigated facilities is the loss of plants both as a result of maladaptation of saplings to tough conditions, the damage caused by animals and irrational management carried out by services exploiting the facility (Fig. 4). In the case of intensive irrigation, the forest stand ought to be changed already after the period of 10 years. The greatest depletion was observed within sections of segment 4 (section 19), where the number of trees decreased by $84.0 \%$. The lowest loss (48\%) was recorded for section 7 (segment 2). Different vegetation species are used on fields irrigated with sewage in order to intensify purification processes. The species used give multiple crops during the growing season, improve the air-ground conditions and accumulate nutrients, e.g. nitrogen and phosphorus. Different grass species can be used, allowing even fourfold crops during the season, which contribute to the high reduction in biogenic compounds (especially nitrogen in the form of nitrate ion) (Jóźwiakowski 2012).

The samples of grass biomass and poplar wood, where a physicochemical composition was marked, were taken from the surface of the purification plant irrigated with sewage (Pawęska and Kuczewski 2008). The physicochemical composition of grass biomass and poplar wood is presented in Table 3. The grass was richer in total N, which in the case of several crops, leads to the increase in the load of pollution removed with the biomass. In the case of trees that have a deeper and more extensive root system, they may acquire nutritional compounds from the deeper parts of the soil profile. Furthermore, once the compounds are built in the biomass, they remain within it for several years. In 2014 the poplars from the irrigated section reached the height of 17 to $32 \mathrm{~m}$. The height of the trees from each of the sections was measured by means of the SUUNTO PM-5/1520 optic meter used for measuring heights of the trees. For the average thickness of poplar wood in air-dry state, determined total mass of wood biomass was equal to $565425 \mathrm{~kg}$ and an immobilised charge within the tree biomass was determined as of the day of drawing up the characteristics of a forest stand (Table 4).

As for the poplar, the charge of total nitrogen and phosphorus accumulated within the biomass remaining on the surface constituted $2.0 \%$ and $2.1 \%$ of the charge accumulated with sewage, respectively. This was the value immobilised within the plants during the 17-year operation period.

The use of the plants on the grounds intensively irrigated with sewage through their increment and accumulation of nutritional compounds improves a general efficiency of sewage purification within the analysed facility. The average efficiency of pollutants reductions was relatively high achieving $91.5 \%$ for $\mathrm{BOD}_{5}$; $89 \%$ for $\mathrm{COD} ; 88.5 \%$ for total nitrogen; 98.4 for ammonium nitrogen and $97 \%$ for total phosphorus. Using wastewater for irrigation of selected species of plants, apart from significant increase of biomass, results in a reduction of pollutants dissolved in wastewater. Organic matter which is source of assimilable carbon, is reduced in mineralization processes due to long interval between individual irrigations. 
Such regime of irrigation results in proper soil ventilation. Additionally, plants uptake of assimilable forms of nitrogen $\left(\mathrm{NO}_{3}{ }^{-}\right)$and phosphorus $\left(\mathrm{PO}_{4}^{-}\right)$from wastewater have an impact on decrease of concentration of these pollutants in the effluent. It was pointed out in the research conducted on system described by authors (Pawęska and Kuczewski 2008, Pawęska and Malczewska 2009) as well as in literature reports (Guidi et al. 2015, Miguel et al. 2014) that objects on which poplars or other selected plants were used as well as soil and microflora, are characterized by high reduction of pollutants dissolved in wastewater..

\section{Summary}

The use of plant and soil facilities with stand density to purify sewage is a complex solution supporting the pollution reduction of different elements of the ecosystem such as suspended solids or biogen compounds. Owing to the use of the capability of the soil environment to retain pollution, the study revealed a considerable reduction in the values of biogen and organic matter concentration and pollution loads in purified sewage discharged. Additionally, the activity of the treatment system supports reduction of an excess of $\mathrm{CO}_{2}$ in atmospheric
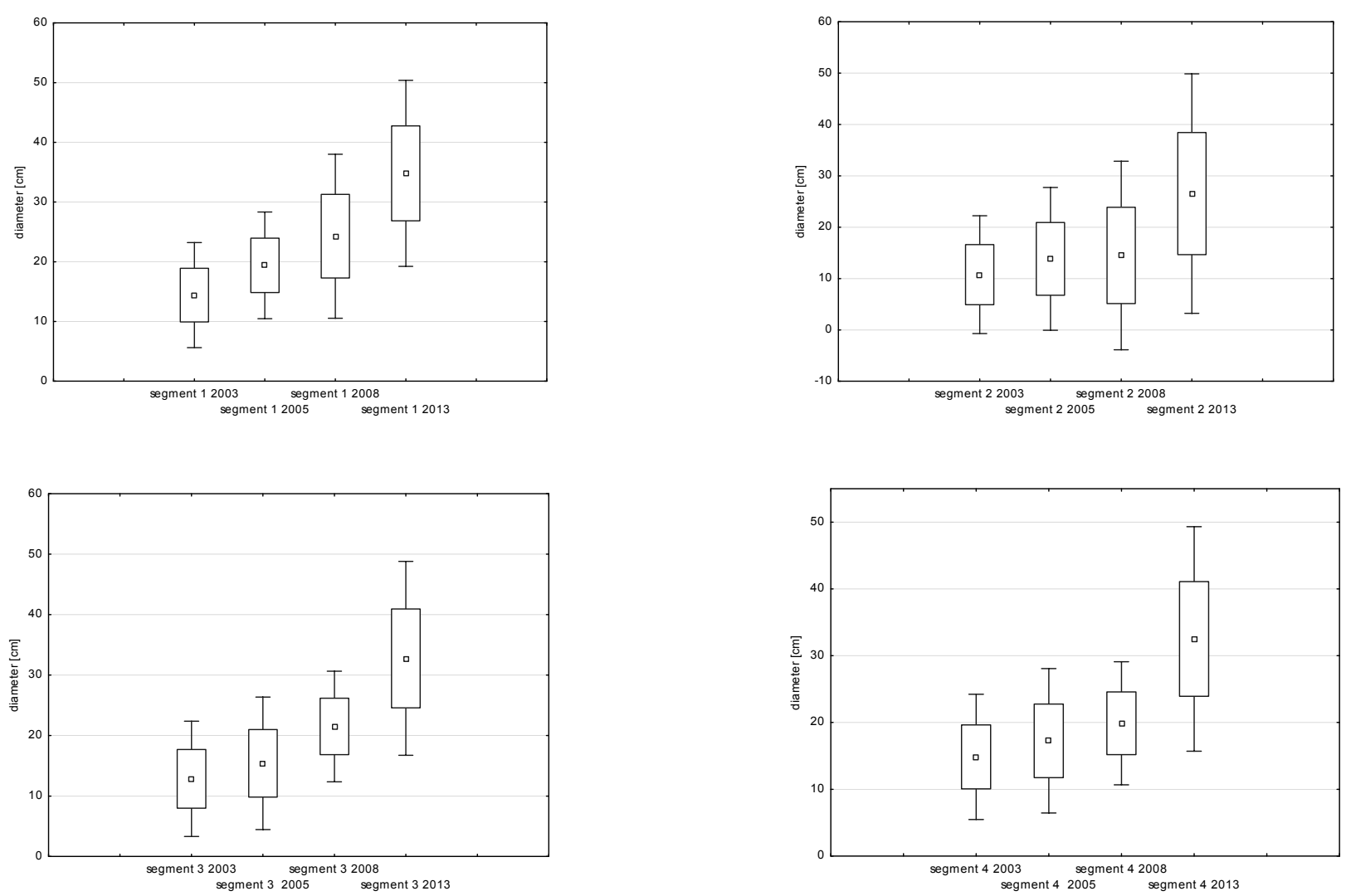

Fig. 4. Changes in $\mathrm{DBH}$ (diameter at breast height) for different segments in object irrigated with domestic sewage in the period of 2003-2013

Table 3. Physicochemical composition of biomass from sewage treatment plant (Pawęska and Kuczewski 2008)

\begin{tabular}{|c|c|c|c|}
\hline \multirow{2}{*}{ Parameter } & 2003 & 2004 & \multirow{2}{*}{$\begin{array}{l}2004 \\
\text { grass }\end{array}$} \\
\hline & \multicolumn{2}{|c|}{ poplar } & \\
\hline Dry mass \% & $61,8-68,8$ & $73,8-83,5$ & 26,7 \\
\hline Humidity $\%$ & $31,2-38,2$ & $16,5-26,2$ & 72,3 \\
\hline Total nitrogen $\mathrm{g} \times \mathrm{kg}$ dry mass $^{-1}$ & $6,8-10,4$ & $3,4-9,3$ & 25,4 \\
\hline $\mathrm{N}-\mathrm{NH}_{4} \mathrm{~g} \times \mathrm{kg}$ dry mass ${ }^{-1}$ & $0,07-0,12$ & $0,054-0,074$ & 3,0 \\
\hline $\mathrm{N}^{-N}{ }_{3} \mathrm{~g} \times \mathrm{kg}$ dry mass ${ }^{-1}$ & $1,03-3,5$ & $0,16-0,40$ & 0,3 \\
\hline $\mathrm{Na} \mathrm{g} \times \mathrm{kg}_{\text {dry } \text { mass }^{-1}}$ & $0,23-0,77$ & $0,31-1,04$ & 1,7 \\
\hline Ca g×kg dry mass ${ }^{-1}$ & $12,87-16,31$ & $7,56-34,15$ & 3,2 \\
\hline Mg g×kg dry mass ${ }^{-1}$ & $0,89-1,09$ & $0,91-1,52$ & 0,6 \\
\hline $\mathrm{K} \mathrm{g} \times \mathrm{kg}$ dry mass ${ }^{-1}$ & $4,6-7,64$ & $3,6-5,0$ & 5,0 \\
\hline $\mathrm{P}$ g×kg dry mass ${ }^{1}$ & $0,67-1,12$ & $0,51-0,81$ & 1,9 \\
\hline
\end{tabular}


Table 4. Load of pollutants accumulated in the biomass of poplars, grasses and pollution load introduced with the wastewater into the sewage treatment plant in Brzeźno and load of pollutants removed with biomass

\begin{tabular}{|c|c|c|c|c|}
\hline Parameter & $\begin{array}{c}\text { Load immobilized } \\
\text { in biomass poplar } \\
2004[\mathrm{~kg}]\end{array}$ & $\begin{array}{c}\text { Load immobilized } \\
\text { in biomass poplar } \\
2014[\mathrm{~kg}]\end{array}$ & $\begin{array}{c}\text { Summary load } \\
\text { introduced with } \\
\text { wastewater 1997-2014 } \\
{[\mathrm{kg}]}\end{array}$ & $\begin{array}{c}\text { \% of load accumulated } \\
\text { in poplar biomass 2014 } \\
{[\mathrm{kg}]}\end{array}$ \\
\hline Total nitrogen & 406,3 & 359,0 & 18120,6 & 2,0 \\
\hline $\mathrm{N}-\mathrm{NH}_{4}$ & 5,1 & 3,6 & 15074,5 & 0,02 \\
\hline $\mathrm{N}-\mathrm{NO}_{3}$ & 14,7 & 13,6 & 416,7 & 3,3 \\
\hline $\mathrm{Na}$ & 63,6 & 38,2 & - & - \\
\hline $\mathrm{Ca}$ & 2283,7 & 1179,2 & 26461,5 & 4,4 \\
\hline $\mathrm{Mg}$ & 58,8 & 68,7 & 3525,8 & 2,0 \\
\hline $\mathrm{K}$ & 105,7 & 243,1 & - & - \\
\hline $\mathrm{P}$ & 59,3 & 50,6 & 2398,6 & 2,1 \\
\hline
\end{tabular}

air through the processes of carbon sequestration in soil (retained in the soil aggregates), intake of the organic matter decomposed as a result of the activity of microorganisms by the plants covering treatment system and assimilation of $\mathrm{CO}_{2}$ from the air by the trees, which are (apart from the soil) the basis for functioning of the treatment system in Brzeźno.

The poplars work perfectly within the treatment system which employs high loads of both an irrigation rate of sewage, and also the sewage load. Selected trees species are characterised by intensive growth which gives the possibility of pollution accumulation into biomass. The highest diameter measured at the height of $130 \mathrm{~cm}$ was observed in the trees of segment 4 (section $20-39.2 \mathrm{~cm}$ ) - after 17 years of exploitation, while the lowest one occurred in the trees planted in segment 2 (section $7-14.9 \mathrm{~cm}$ ). The most intensive increment in the diameters, around $2.7 \mathrm{~cm}$ annually, was observed in years 2005-2008.

The load of pollution accumulated in the poplar biomass was lower than the load removed with grass crops. A disproportion in the levels of removed pollution was caused, among other things, by the lack of forest stand replenishment and acquiring nutritional components by the plants from different levels of the soil profile.

As a result of intensive irrigation of poplars, quite shallow root system is generated and because of this the trees are easily impacted by destructive wind power (windfalls and windfallen trees). This phenomenon, along with annual cutting out of the trees, was the basis for determination of percentage losses. The greatest loss of the forest stand was observed during the first years of the facility operation $(43.2 \%)$, while in subsequent years the forest stand losses were at lower levels 9.3\%; $38.7 \%$ and $14.3 \%$ in $2005 ; 2008$ and 2014, respectively. The construction of plant-soil treatment system, where the surface is covered with gramineous vegetation and trees (poplars) constitutes an effective solution of sewage management on rural areas.

\section{References}

Badura, L. (2006). Consideration of role of microorganisms in soil, Zeszyty Naukowe Uniwersytetu Przyrodniczego we Wrocławiu, Rolnictwo LXXXIX, 546, pp.13-25. (in Polish)
Baryła, R. (2005). Evaluation of the usefulness of purified sewage for irrigation of grass communities, Annales Universitatis Mariae Curie-Skłodowska Lublin-Polonia, LX, E, pp.123-132. (in Polish)

Bień, J. \& Nowak, D. (2014). Biological composition of sewage sludge in the aspect of threats to the natural environment, Archives of Environment Protection, 40, 7, pp.79-86.

Boćko, J. (1979). Perspectives of irrigation with waste waters and its importance in the environment protection, Zeszyty Problemowe Postępów Nauk Rolniczych, 217, pp. 249-258. (in Polish)

Bugajski, P. \& Satora, S. (2009). The balance of sewage inflowing and brought to the treatment plant based on example of the chosen object, Infrastruktura i Ekologia Terenów Wiejskich, 5, pp. 73-81. (in Polish)

Bouwer, H. (1992) Agricultural and municipal use of wastewater, Water Science and Technology, 26,7-8, pp. 1583-1591.

Carr, R.M., Blumenthal, U.J. \& Mara Duncan, D. (2004). Guidelines for the safe use of wastewater in agriculture: revisiting WHO guidelines, Water Science and Technology, 50,2, pp. 31-38.

Fine, P., Atzmon, N., Adani, F. \& Hass, A. (2006). Disposal of sewage effluent and biosolids in eucalyptus plantations: a lysimeter simulation study, Soil and Water Pollution Monitoring, Protection and Remediation, NATO Sciences Series, 69, pp. 433-453.

Freedman, B. (2014). Maintaining and enhancing ecological carbon sequestration, Global Environmental Change, Handbook of Global Environmental Pollution, 1, pp. 783-801.

Guidi Nissim, W., Jerbi, A., Lafleur, B., Fluet, R. \& Labrecque, M. (2015). Willows for the treatment of municipal wastewater: Performance under different irrigation rates, Ecological Engineering, 81, pp. 395-404.

Joniec, J., Furczak, J. \& Baran, S. (2012). The importance of sludge microorganisms in nitrogen transformation in podzolic soil amended with sewage sludge, Archives of Environment Protection, 38,1, pp. 35-47.

Jóźwiakowski K. (2012), Studies on the efficiency of sewage treatment in choosen constructed wetland system, Infrastruktura i Ekologia Terenów wiejskich, PAN Oddział w Krakowie, Komisja Technicznej Infrastruktury Wsi, Rozprawa habilitacyjna. (in Polish)

Jóźwiakowski, K. (2005). Chemical properties of reed and willow from ground beds of small wastewater treatment plants on rural areas, Infrastruktura i Ekologia Terenów Wiejskich, 1, pp. 5-14. (in Polish)

Lal, R. (2004). Soil carbon sequestration to mitigate climate change, Geoderma, 123, pp. 1-22. 
Miguel, A., Meffe, R., Leal, M., Gonzalez-Naranjo, V., MartinezHernandez, V., Lillo, J., Martin, I., Salas, J.J. \& Bustamante, I. (2014) Treating municipal wastewater through a vegetation filter with a short-rotation poplar species, Ecological Engineering, 73, pp. $560-568$.

Montiel-Vasquez, O., Horan, J.N. \& Mara, D.D. (1995). Management of domestic wastewater for reuse in irrigation, Water Science and Technology, 33, 10-11, pp. 355-362.

Oster, J.D (1994). Irrigation with poor quality water, Agricultural Water Management, 25, 3, pp. 271-297.

Paluch, J. (1984). Treatment of municipal sewage in soil environment, Zeszyty Naukowe Akademii Rolniczej, 41.

Pandey, A. \& Srivastava, R.K. (2012). Wastewater treatment efficiency and biomass growth of short rotation bio-energy trees in modified overland flow land treatment system, International Journal of Environmental Science, 3,1, pp. 591-604.

Paustian, K. (2014). Carbon sequestration in soil and vegetation and greenhouse gases emissions reduction; global environmental change, Handbook of Global Environmental Pollution, 1, pp. 399-406.

Pawęska, K. \& Kuczewski, K. (2008). Effectiveness of domestic sewage purification in plant-soil treatment plants with differ operating, Wspótczesne Problemy Inżynierii Środowiska IX, Monografie LX. (in Polish)
Pawęska, K. \& Malczewska, B. (2009). Nitrogen compounds in drain sewage after constructed wetlands, Water Science Technology, 60(10), pp. 2613-2619.

Pedrero, F., Kalavrouziotis, I., Alarcon, J.J., Koukoulakis, P. \& Asano, T. (2010). Use of treated municipal wastewater in irrigated agriculture - Review of some practices in Spain and Greece, Agricultural Water Management, 97, 9, pp. 1233-1241.

Różanowski, B., Michałowski, M., Tora, B., Cablik, V. \& Cernotova, L. (2012). Effectiveness of the use of willow tree (Salix viminalis) for wastewater treatment, $A G H$ Journal of Mining and Geoengineering, 36, 4, pp. 159-165.

Tanner, C.C. (2001). Plants as ecosystem engineers in subsurfaceflow treatment wetlands, Water Science and Technology, 44, 11-12, pp. 9-17.

Wiśniewska-Kadżajan, B. \& Jankowski, K. (2012). Susceptibility of sewage water from household sewage treatment to lawn watering, Ochrona Środowiska i Zasobów Naturalnych, 54, pp. 200-209. (in Polish)

Sanchez-de Leon, Y., Lugo-Perez, J., Wise, D.H., Jastrow, J.D. \& Gonzalez-Meler, M.A. (2014). Aggregate formation and carbon sequestration by earthworms in soil from a temperate forest exposed to elevated atmospheric $\mathrm{CO}_{2}$ : a microcosm experiment, Soil Biology and Biochemistry, 68, pp. 223-230.

\section{Zmiany przyrostów średnic drzew na terenie oczyszczalni roślinno-glebowej po okresie wieloletnich nawodnień ściekami bytowymi}

Streszczenie: Sekwestracja dwutlenku węgla, jego długotrwałe unieruchomienie w biomasie jest ostatnio problemem niezwykle istotnym. Największe jego rezerwy znajdują się w lasach porastających kule ziemską. Człowiek poprzez swoje świadome działanie powinien wpływać między innymi na ilość dwutlenku węgla odprowadzanego do atmosfery oraz na racjonalne gospodarowanie nim. Dość dobrym rozwiązaniem zdaje się tu być unieruchomienie $\mathrm{CO}_{2}$ w biomasie roślin, a w szczególności w charakteryzujących się długowiecznością drzewach, które wykorzystywane są w tym celu najczęściej. Taka gospodarka dwutlenkiem węgla pozwala na kilkudziesięcioletnie unieruchomienie go w żywych roślinach, natomiast dalsza przeróbka masy drzewnej na zatrzymanie go przez kolejne lata w wytworzonych produktach. Dodatkowo w przypadku kiedy na wybranym, obsadzonym drzewami terenie prowadzi się nawodnienia ściekami, korzyścią jest również równoczesne oczyszczanie ścieków. Przy wykorzystaniu na obiektach roślin charakteryzujących się intensywnym przyrostem biomasy można również efektywnie usunąć biogeny znajdujące się w ściekach.

W analizowanym przypadku oczyszczanie ścieków polegało na wprowadzeniu na przygotowaną powierzchnię ścieków bytowych, poddanych wcześniej mechanicznemu oczyszczeniu. Wszystkie kwatery obsiano mieszanką traw oraz zastosowano nasadzenia topolowe. Obserwacje prowadzono przez okres 17. lat. Analizie fizykochemicznej poddawano ścieki wprowadzane na powierzchnię kwater oraz odpływające z obiektu celem określenia skuteczności pracy oczyszczalni roślinno-glebowej. Przeprowadzono również trzykrotną inwentaryzację drzewostanu w celu określenia przyrostu drzew.

Ostatnią inwentaryzację wykonano w roku 2014. Na podstawie charakterystyki dendrologicznej oszacowano średnią miąższość masy drzewnej uzyskanej z terenu nawadnianego ściekami.

Racjonalna gospodarka ściekami na terenach bez centralnej kanalizacji pozwala na równoległe rozwiązanie kilku problemów. Przede wszystkim oczyszczanie ścieków w środowisku naturalnym poprzez zamykanie obiegu materii, a dodatkowo przyczynianie się do ograniczenia emisji dwutlenku węgla poprzez zatrzymywanie go w biomasie roślin. 